\title{
Thermochromic $\mathrm{VO}_{2}$ films for smart windows application
}

\author{
M. Azzi ${ }^{1,2}$, R. Slim¹, K. Khoury ${ }^{1}$, S. Loquai², B. Baloukas², L. Martinu² \\ ${ }^{1}$ Lebanese University, Faculty of Engineering, Beirut Lebanon \\ ${ }^{2}$ Ecole Polytechnique de Montréal, Montréal, Canada
}

Keywords: Thermochromic, VO2, Smart windows, Energy saving

\section{Introduction}

Following the misdeeds of industrialization and consumerism of the last century, the greatest challenges of the new millennium will be to cope with global warming and energy conservation. A significant amount of energy is consumed nowadays for maintaining thermal comfort in buildings [1, 2].

Windows are known as one of the most energy inefficient components of buildings [3]. With up to $60 \%$ of the total energy loss of a building coming from its windows [4], fenestration products have a huge potential to provide large energy savings [5]. Two properties define the energetic behaviour of windows: (1) thermal transmittance, or Uvalue, and (2) solar factor or g-value. The first determines the heat flow across a window while the second factor determines the amount of solar energy passing through the window.

Several solutions have been proposed to improve the energy performance of windows. For the reduction of the U-value, multilayer glazing [6] and vacuum glazing $[7,8]$ have been developed. For the limitation of solar gain in the hot season, low emissivity (low-e) coatings $[9,10]$ are used to let the visible light pass through and block the IR and UV wavelengths which generally create heat [11]. Because of its high IR-reflectance, this type of glazing has been substantially developed during the last two decades [12].

Vanadium dioxide VO2 is one of the most important thermochromic materials due to a phase change that takes place at $68^{\circ} \mathrm{C}$. Its practical use in smart windows for building is still facing many difficulties, mainly high transition temperature, low transmittance in the visible range and high deposition temperatures [13,14].

This work is divided into two parts; first, a building energy simulation is carried out first to estimate the energy saving potential and to determine suitable properties of smart windows for the Lebanese climate, second, deposition of VO2 has been studied using two different deposition techniques namely the carried out using two different techniques namely the conventional Radio Frequency Magnetron Sputtering (RFMS) and the High Power Impulse Magnetron Sputtering (HiPIMS). 


\section{Results}

Energy Simulation: Simulation work has shown that the use of TC windows in a typical office space in Beirut can introduce around $15 \%$ economies in the overall energy needs, including space heating, space cooling and artificial lighting. This figure was obtained when comparing TC-coated glass with clear glass. Study was based on $100 \mathrm{~m}^{2}$ office building floor located on the coastal area of Lebanon simulated through EnergyPlus 8.1. However, it is necessary to underline that these encouraging results pertain to theoretical thermochromic windows, having a transition temperature of $35{ }^{\circ} \mathrm{C}$ and a switching range as wide as $5{ }^{\circ} \mathrm{C}$, which seems to allow maximizing energy savings under all different conditions. In addition, value of daylight luminance in summer was found to be less than the minimum value, Emin=300 $\mathrm{lx}$, due to the transition to tinted state.

$\mathrm{VO}_{2}$ Deposition: Deposition results show that HiPIMS gives higher density films due high energy ions bombarding the substrate during deposition and therefore leads to better film durability. Furthermore, SiN deposited as top layer and interlayer was shown to improve significantly the durability of $\mathrm{VO}_{2}$ layer as $\mathrm{SiN}$ acts as a barrier layer against humidity and improve the adhesion.

$\Delta T_{2500 \mathrm{~nm}}$ parameter defined as the infrared optical modulation at $2500 \mathrm{~nm}$ wavelength (see schematic in Fig. 1) was used to determine the quality of the thermochromic film. It was shown that the deposition temperature Tc affects substantially $\Delta \mathrm{T}_{2500 \mathrm{~nm}}$. For Tc < $300^{\circ} \mathrm{C}, \Delta \mathrm{T}_{2500 \mathrm{~nm}}$ was found to be less than $30 \%$, however for $\mathrm{Tc}>300^{\circ} \mathrm{C}$, values of $\Delta \mathrm{T}_{2500 \mathrm{~nm}}$ exceed $30 \%$ to reach almost $45 \%$.

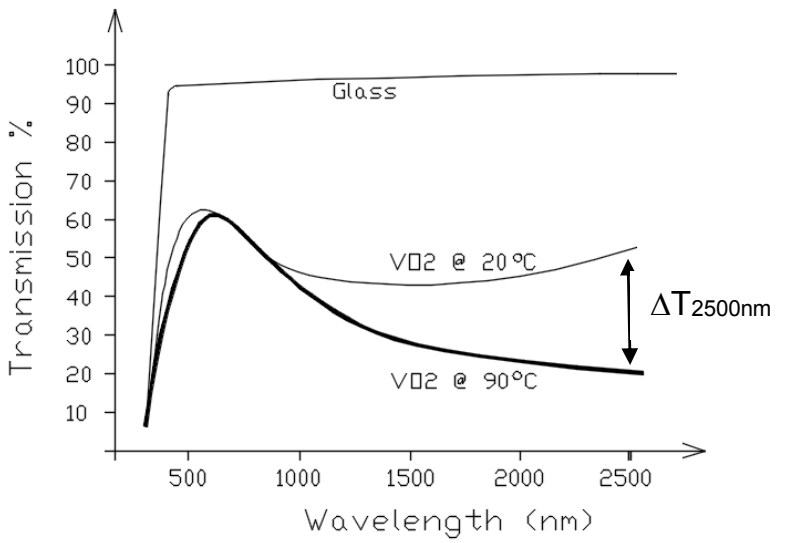

Fig. 1: Schematic graph showing the variation of the transmission spectra for a VO2 thin film at low and high temperature phases, and definition of $\Delta T_{2500 \mathrm{~nm}}$. 


\section{Conclusions}

1- Thermochromic VO2 coatings have been studied for potential use in smart window applications.

2- Simulation work has shown that the use of TC windows with transition temperature around $35^{\circ} \mathrm{C}$ in a typical office apartment in Beirut can introduce around $15 \%$ economies in the overall energy needs in office.

3- VO2 layer deposited by HiPIMS was shown to have higher density due high energy ions bombarding the substrate/layer during deposition and therefore leads to better film durability.

4- SiN deposited as top layer and interlayer was shown to improve significantly the durability of VO2 layer.

\section{References}

[1] M. Kamalisarvestani, R. Saidur, S. Mekhilef, F.S. Javadi, Performance, Renewable and Sustainable Energy Reviews 26 (2013) 353-364.

[2] Department of Energy U. Buildings energy data book. Energy Efficiency \& Renewable Energy. 2011.

[3] Baetens R, Jelle BP, Gustavsen Solar Energy Materials and Solar Cells. 2010; 94 (2):87105.

[4] A.Gustavsen, B.P.Jelle, D.Arasteh, C.Kohler, Project Report 6, SINTEF Building and Infrastructure, 2007.

[5] B. P. Jelle, A. Hynd, A. Gustavsen, D. Arasteh, H. Goudey, R. Hart, Solar Energy Materials and Solar Cells 96 (2012) $1-28$.

[6] H. Manz, Renewable Energy 33 (2008) 119-128.

[7] P.C. Eames, Vacuum 82 (2008) 717-722.

[8] Y. Fang, T. Hyde, N. Hewitt, P.C. Eames, B. Norton, Solar Energy Materials and Solar Cells 93 (2009) 1492-1498.

[9] K. Chiba, T. Takahashi, T. Kageyama, H. Oda, Low-emissivity coating of amorphous diamond-like carbon/Ag-alloy multilayer on glass, Applied Surface Science 246 (2005) 48-51.

[10] M. Reidinger, M. Rydzek, C. Scherdel, M. Arduini-Schuster, J. Manara, Thin Solid Films 517 (2009) 3096-3099.

[11] Sadineni SB, Madala S, Boehm RF. Renewable and Sustainable Energy Reviews 2011; 15 (8): 3617-31.

[12] Huang S, et al. Thin Solid Films 2008; 516 (10): 3179-83.

[13] Kivaisi R, Samiji M. Solar Energy Materials and Solar Cells 1999; 57 (2): 141-52.

[14] Li S-Y, Niklasson GA, Granqvist CG. Thermochromism MRS proceedings. Cambridge Univ Press;2011. 